\title{
Skill Development through Higher Education
}

\author{
Dr Rintu Saikia ${ }^{1}$, Meghali Borah ${ }^{2}$ \\ ${ }^{1}$ Senior Technical Assistant, Department of Agricultural Engineering, Assam Agricultural University, Jorhat-13 \\ ${ }^{2}$ Lecturer, Department of Economics, Law College, Jorhat-1
}

\begin{abstract}
Everybody knows it is impossible to learn to ride a bicycle by reading a book. It needs practice; and that perfection of learning to ride a bicycle which one obtains through dedicated practice and labour, is the skill which cannot be achieved by any other means. Likewise skill development is not an easily obtainable talent of any human being. The skill of perfection which our forefathers obtained in their crafts or handicrafts were not attained by sudden awakening. It was only through constant practice, perfection was attained. One may talk of Leonardo, Mozart, Raphael, Galileo, Alva Edison...etc. leads one to think about the gifted or the inborn talent which they acquired in fulfilling their art, but one never gets into the insights of the stress of constant labour and dedication which they overcame in becoming what they were. Thus skills are not developed, but obtained through a constant process of sincerity, devotion, hard work and constrained study towards the activity on which anyone is engaged. How to develop these characteristics in the students while pursuing a degree in Higher Education would be stressed in this paper. Also how to induce, utilizing individual talents of the students in higher education through motivating, facilitating, and inspiring by providing a proper environment of growth such that when they are out of college they are accepted by the societyas a source of wisdom would also be looked into.
\end{abstract}

Keywords: Skills, Skill development, Skill transfer, skill perfection, proper environment, Individual capacities

\section{Introduction}

After two decades of formal educational training which includes schooling, higher secondary, college, masters then a $\mathrm{PhD}$, who after toiling through the academic rigours lands an individual into unemployment, there is a question to be answered - Who is responsible? Why are the individuals unable to cope with the labour requirements of the society? Are they not trained properly such that they can use their own hands or capacities to earn their own livelihoods? Are the individuals unable to place themselves in the job market? Are unable to run their ancestral properties? According to NAASCOM-McKinsey report, in India only $25 \%$ of fresh engineers; and a mere $10 \%$ of fresh graduates are actually employable! Then what is employability? How can the individuals be made employable?

The facilities with which young people are induced to acquire knowledge, without study or labour, is not education. It occupies but does not enrich the mind. It imparts a stimulus for the time and produce a sort of intellectual keenness and cleverness, but without an implanted purpose and a higher object then mere pleasure, it will bring with it no solid advantage. In such cases knowledge produces but a passing impression, a sensation, but no more; it is in fact the merest epicures of intelligence sensuous, but certainly not intellectual. Thus best qualities of many minds, those which are evoked by vigorous effort and independent action, sleep a deep sleep, and are often never called to life, except by the rough awakening of sudden calamity or suffering, which in such cases, comes as a blessing, if it serves to rouse up a courageous spirit that, but for it would have slept on.The experience gathered from books, is but a nature of learning; whereas the experience gained from actual life is of the nature of wisdom; and a small store of the latter is worthy vastly more than any stock of the former.

\section{The Goal of Education}

The chief object of education is not to fill the mind with other men's thoughts, and of passive recipient of their impressions of things, but to enlarge our individual intelligence, and to render us more useful and efficient worker in the sphere of life to which we may be called. Many of the most energetic and useful workers have been but sparing readers. It is not, then, how much one may know that is of importance, but the end purpose for which one knows it. The object of knowledge should be to mature wisdom and improve character, to render individuals better, happier and more useful; more benevolent, more energetic, and more efficient in the pursuit of very high purpose in life.Students must be taught to help themselves be and do, and not rest satisfied merely with reading and meditating over what other men have been and done. Their best light be made life, and best thought action by providing a proper environment of growth both physical and intellectual within the confines of the institutional campus.

\section{Skill Transmission}

The perspective is somewhat different as far as skills are concerned, because a skill which is not transmitted to a new generation will simply disappear, this is what makes education so different from the traditional transmission of knowledge. The knowledge of specific principles which have developed in a certain period can easily be forgotten for a while and then be recalled at a later time. Skills, however, cannot be stored in the same way. They cannot be easily abandoned and recalled; they have to be transmitted in order to survive and this is why training is so important. Skills must be transmitted from teacher to pupil, from master to apprentice, from one generation to the other. In understanding how academic institutions have been created, one understands better how skills have been transmitted, and how skills have been affected by this very transmission through the centuries. 


\section{International Journal of Science and Research (IJSR)}

\section{Why Skills development is required:}

Quality manpower forms the backbone of a developed economy. Excellence in manpower development and utilization of superior skills shapes the future which contributes silently in world development. The educational diet being handed out at our educational institutions is not a lean diet, by any standards. It is rich in content, but appears somewhat imbalanced in emphasis. Like the diet of the ignorant affluent, it is often more decorative than functional, catering rather to the palate than to the needs of the body growth. Before analysing the shortcomings in the existing system, it is necessary to be clear about the objectives.

Technology does not accumulate like scientific knowledge through history. Science has developed through the accumulation of knowledge over centuries and mankind has reached new understanding and new insights into the nature of reality by adding one discovery to another. This is in fact one of the characteristic features of our civilization. Nobody can argue that the world has not changed dramatically in the recent years, and continues to change with amazing speed. Yet, we have not changed the basic approach to educating our children for the past 200years. Will our current approach to education be adequate to equip these children to face the emerging world? Can we continue with our assembly-line approach to teaching our children, rather than acknowledging and nurturing the unique gifts and talents that each one of them represents? Should education be restricted primarily, to the first 20-25 years of our lives? Or should the focus shift to a life-long learning?

Alvin Toffler, in "The Third Wave" describes mass education as being built on the industrial age factory model to teach basic reading, writing and arithmetic, a bit of history and other subjects - the overt curriculum. Beneath it was the covert curriculum that was far more basic. It consisted of three courses - punctuality, obedience and repetitive work the basic training requirements to produce reliable, productive factory workers. Will the $21^{\text {st }}$ century world require just these capabilities?

\section{Limits of human intelligence:}

There are no physical limitations to inner vision ....... The psychic faculties of man know no barriers of space or time. A world of marvellous phenomena awaits to be at the command of the human mind are dormant power that can bring about a transformation in the world and improve the quality of life. When the goal of education is coincided with the goal to develop socially useful developed human minds, it would boost the productivity of the educational institutions, which in turn would help nurture individual minds in their own way, as it would give a chance to the individuals to explore their own selves. If education helps the individuals to determine their purpose, functions and powers as human being.

Coinciding the goal of education to developing socially useful developed human minds, by breaking the boundary walls of the enforced curriculums and allowing the inflow of various ideas from individual minds, would boost the performance of the educational institutions. The function of the institutions would then be to guide the individuals to determine their purpose, functions and powers as a human being. History has the examples of individuals who with their will power reached undreamt heights in their lives. What becomes of all the "remarkably clever children?" where are all the dukes and prize boys? Trace them through life, and it will frequently be found that the dull boys, who were beaten at school, have shot ahead of them. The clever boys are rewarded, but the prizes which they gain by their greater quickness and facility do not always prove of use to them. What ought rather to be rewarded is the endeavour, the struggle, and the obedience; for it is the youth who does his best, though endowed with an inferiority of natural powers, that aught above all others to be encouraged.

\section{Human Development and the Environmental Conditions}

No individual in the universe stands alone; he is a component part if a system of mutual dependencies; and by his several acts he either increases or diminishes the sum of human good now and for ever. Every act we do or word we utter, as well as every act we witness or word we hear, carries with it an influence which extends over, and gives colour, not only to the whole of our future life, but makes itself felt upon the whole frame of the society. We may not, and indeed cannot, possibly trace the influence working itself into action in its various ramifications amongst our children, our friends, our associates; yet there it is assuredly, working on for ever. And herein lies the great significance of setting forth a good example, - a silent teaching which even the poorest and least significant person can practice in his daily life. There is no one so humble but there he owes to others this simple but priceless instruction. Even the meanest condition may thus made useful; for the light set in a low place shines as faithfully as that set upon a hill.

\section{Places where skills are developed}

Everywhere, and under almost all circumstances, however externally adverse - in moorland shielings, in cottage helmets, in the close alleys of great towns - the true man may grow. The commonest workshop may thus be a school of industry, science, and good morals, on the one hand; or of idleness, folly, and depravity, on the other. "The best part of every man's education", said Sir Walter Scott "is that which he gives himself". The education received at school or college is but a beginning, and is valuable mainly in as much as it trains the mind and habituates it to continuous application and study. That which is put into us by others is always far less our than that which we acquire knowledge by the active exercise than upon telling, and sought to make their pupils themselves active parties to the work in which they were engaged, thus making teaching something far higher the mere passive reception of the scraps and details of knowledge.

\section{Obstructions in skill development}

Though human being is termed a reasoning animal, their conduct is not guided by logic and reason. Passions, vanity, honour, and short term interests often govern their

\section{Volume 6 Issue 7, July 2017 www.ijsr.net}




\section{International Journal of Science and Research (IJSR) \\ ISSN (Online): 2319-7064}

Index Copernicus Value (2015): 78.96 | Impact Factor (2015): 6.391

generalbehaviour. They are victims of local pressures and national obsessions. But human beings tend to lose their creativity when they feel and nothing gets better, they cannot improve anything, their daily life is controlled by pressures and they hear from philosophers' echoes of their anxiety and despair. The challenges, the values of spirit, the pursuit of truth and the practice of love which have nourished the great pages of history do not seem to be relevant to an age steepened in science, deserted by religion and deprived of even humanist ideals. The two legged creature seem to have reached the height of irresponsibility. Though human is rooted in nature, they also exceed nature. Regarding the future there is nothing sure or predestined or guaranteed. The only certainty is that the good will prevail over evil. The spirit of the individual human beings is the source of their freedom.

The crisis that is facing the present day world is not material or an economic crisis; it is not an intellectual crisis. It is a moral or spiritual crisis.Humanity have mastered the forces of nature. Human intellectual achievements are unparalled. If in spite of these possibilities of material abundance and intellectual power, peace is still in peril, it is due to a cussedness in human nature which still persists, a moral blindness, a spiritual affliction which they are unable to overcome. Human beings are suffering from a split mind. Not only the atom has been split in modern times, but our minds, hearts and conscience. It is simpler and easier to remake the face of the material environment. To remake human inward nature, to accept the values of spirit which make for a creative living, justice, freedom and equality is a harder task. The evil in the human nature has to be conquered. What human beings need is the inner development of themselves, of individuals as a spiritually, morally and socially creative being. Humans kneed a change of heart, a conversion of the soul.

Science and technology have relieved mankind of degrading drudgery. Science has added to the degree and stature of the individual. When human beings are relieved from the battle for physical safety, theyget time to become a little creative. Every challenge of science has added to man's moral stature. As we find the world is much more wonderful than we ever dreamt it to be, we are led into new fields of awareness, new ranges of attainments, new realization of destiny which can led to awesome inventions or discoveries. New knowledge is both a challenge and an opportunity. For it is not yet known what man may be. He must without haste and without rest, strive to reach the quality of human greatness that is greatness in humanity. Mankind is the higher sense of the planet.

When mankind realizes its destiny of inward awareness and social compassion, then the greatness reconciliation among the peoples of the world in which all groups win and no one loses will take place. The limits of the community are worldwide and are decided by attitudes of mind and not frontiers of geography. Education deals with individuals. Tagore says I do not put my faith in any new institution, but in the individuals all over the world, who think clearly, feel nobly and act rightly, thus becoming the channels of moral truth. It is wrong to assume that events are sweeping mankind towards unknown and predestined ends. Human beings are not the helpless pawns of natural forces. There is an element in man which cannot be accounted for by nature. Humans have advanced across the centuries through creative evolution. They need courage to change to scrap old prejudices, old approaches to international problems. By mastering the evil forces one gets the freedom of mind to dream and develop the harnessing new energies through which one can raise human wellbeing to undreamt of levels. As men are freed from the battle of physical existence, they will press forward in their struggle against ignorance, suspicion, malice and hatred. Our intellectual achievements are unparalleled. It is seen that humans have the capacity for monstrous deeds, the susceptibility of even the gifted to delusion and of the seemingly decent persons for malice and hatred. To exist is to be self-conscious being vividly aware of oneself and engaged in a great personal adventure. All historical facts are acts of men. Men make history. The world is subject to time, historicity, and change. Life is haunted by death, beauty by decay. Nothing abides; everything passes away. Impressed by the vanity of our projects, the futility of our achievements, the restlessness of temporal life, its confusions and contradictions, its ultimate nothingness, the Buddha tells us that each one has to pass through it all in order to fulfill himself and recognize at the depth of all struggle the lasting peace of nirvana. A bushel of wheat has two possible destinies to be pounded and made into flour and become bread; or be sown in the ground, to germinate and become a plant, and give a hundred grains for one that is sown.

Man is not a complete final being. He is a being who can transform himself, who can be born again. We must have vivisa(future), faith, sraddha(respect), that there is something superior to the things of this world. Mere faith, blind unthinking faith, will not do. We must have knowledge. By reflection we convert the product of faith into a product of enlightenment. But mere theoretical knowledge is not enough. We cannot get life eternal by mere textual learning. We must embody these principles in our own life, criteria, conduct is equally essential.

Taking all of these into consideration, there is a requirement for the construction of a gyroscopic and intelligent educational system where the sensors of the system automatically warn the management to place it in the right direction. The students are to be trained in such a way that they can choose own way of learning aligning to their own lifestyle. In an era where one day the technology is innovated, the day after it is outdated; it is very difficult to find the requirement of the future generation. In the race to fight against this technological aggression, speed and flexibility is vital. Thus designing for flexibility, reliability, quality and relevance in Higher Education is a must to survive and let the society survive. In the manufacturing industries quality failure meant life and death. It brought to mind the proverb from Poor Richard's Almanac: "A neglect may breed great mischief. For want of a nail......the rider was lost". Thus for the want of a proper training and skill development once a bright student would be reduced to a pauper.

\section{References}

Volume 6 Issue 7, July 2017 www.ijsr.net

Licensed Under Creative Commons Attribution CC BY 


\section{International Journal of Science and Research (IJSR) \\ ISSN (Online): 2319-7064}

Index Copernicus Value (2015): 78.96 | Impact Factor (2015): 6.391

[1] Avinashilingam, T.S.Education Swami Vivekananda. Compiled and edited Published by Sri Ramkrishna Mission VidyalayaPerianaickenpaalyam, Coimbatore.

[2] S.Radhakrishnan, Religion and Culture (C) S.Radhakrishnan1968Published by Hind Pocket Books(P)LTD., G.T.Road, Delhi 32

[3] Gandhi Vigyan Journal of the academy of Gandhian Studies, Hydrabad, Andhra Pradesh. Special Issue EDUCATION, January 1978.

[4] Edited by Norman Cousins.Profiles of Gandhi, America remembers a world leader. Published by Indian Book Company, Kashmere Gate Delhi-6. 1969

[5] Richard Breese1, Graham Eyre2 and Peter Cogill2Case Study Change Management - Practising what we Teach: Issues in Engaging International Students in Learning, Teaching, \& Assessment Student Engagement and Experience Journal Volume 1, Issue 1 ISSN (online) 2047-9476

[6] Lyndsay Swinton Kurt Lewin's Force Field Analysis: Decision Making Made Easy Management For The Rest Of Us www.mftrou.com

[7] Fred C. LunenburgSam Houston State University Forces for and Resistance to Organizational Change NATIONAL FORUM OF EDUCATIONAL ADMINISTRATION AND SUPERVISION JOURNAL VOLUME 27, NUMBER 4, 2010

[8] Sri RintuSaikiaBeyond Academic Curriculum: Embedding Employability Skills in Agricultural Education in Assam Agricultural University International Journal of Social Sciences and Entrepreneurship Vol.1, Issue 9, 2014 http://www.ijsse.org ISSN 2307-6305

[9] RintuSaikia, DrPranjalBezborah Quality and Relevance in Higher Education International Journal of Scientific \& Engineering Research, Volume 5, Issue 2, February-2014 945 ISSN 2229-5518 IJSER (C) 2014 http://www.ijser.org 